\title{
Repetitive Self-Grooming Behavior in the BTBR Mouse Model of Autism is Blocked by the mGluR5 Antagonist MPEP
}

\author{
Jill L Silverman*,', Seda S Tolu', Charlotte L Barkan' and Jacqueline N Crawley' \\ 'Laboratory of Behavioral Neuroscience, National Institute of Mental Health, Porter Neuroscience Research Center, Bethesda, MD, USA
}

Autism is a neurodevelopmental disorder characterized by abnormal reciprocal social interactions, communication deficits, and repetitive behaviors with restricted interests. BTBR $T+t f / J ~(B T B R)$ is an inbred mouse strain that shows robust behavioral phenotypes with analogies to all three of the diagnostic symptoms of autism, including well-replicated deficits in reciprocal social interactions and social approach, unusual patterns of ultrasonic vocalization, and high levels of repetitive self-grooming. These phenotypes offer straightforward behavioral assays for translational investigations of pharmacological compounds. Two suggested treatments for autism were evaluated in the BTBR mouse model. Methyl-6-phenylethynyl-pyridine (MPEP), an antagonist of the mGluR5 metabotropic glutamate receptor, blocks aberrant phenotypes in the Fmrl mouse model of Fragile $\mathrm{X}$, a comorbid neurodevelopmental disorder with autistic features. Risperidone has been approved by the United States Food and Drug Administration for the treatment of irritability, tantrums, and self-injurious behavior in autistic individuals. We evaluated the actions of MPEP and risperidone on two BTBR phenotypes, low sociability and high repetitive self-grooming. Open field activity served as an independent control for non-social exploratory activity and motor functions. C57BL/6J (B6), an inbred strain with high sociability and low self-grooming, served as the strain control. MPEP significantly reduced repetitive self-grooming in BTBR, at doses that had no sedating effects on open field activity. Risperidone reduced repetitive selfgrooming in BTBR, but only at doses that induced sedation in both strains. No overall improvements in sociability were detected in BTBR after treatment with either MPEP or risperidone. Our findings suggest that antagonists of mGluR5 receptors may have selective therapeutic efficacy in treating repetitive behaviors in autism.

Neuropsychopharmacology (2010) 35, 976-989; doi:10.1038/npp.2009.201; published online 23 December 2009

Keywords: autism; social behavior; repetitive behavior; mouse models; mGluR5; BTBR

\section{INTRODUCTION}

Autism is a neurodevelopmental disorder affecting approximately 1 in 150 children (Landa, 2008). Diagnosis is behaviorally defined by three core symptom domains: unusual reciprocal social interactions, impaired communication, and stereotyped, repetitive behaviors with restricted interests (DiCicco-Bloom et al, 2006; Geschwind et al, 2001; Happe and Ronald, 2008; Lord et al, 2000). Linkage and association studies have identified large numbers of de novo and familial candidate genes that may be responsible for susceptibility to autism (Abrahams and Geschwind, 2008; Bourgeron, 2009; Buxbaum, 2009; Lintas and Persico, 2009; Persico and Bourgeron, 2006). Pharmacological treatments for symptoms of autism are currently under investigation. Several potential therapeutic targets have

*Correspondence: Dr JL Silverman, Laboratory of Behavioral Neuroscience, National Institute of Mental Health, NIH, Porter Neuroscience Research Center Building 35 Room IC-707, 9000 Rockville Pike, MSC 3730, Bethesda, MD 20892, USA, Tel: 30I-45I-9388, Fax: 30I-480-1315, E-mail: silvermanj@mail.nih.gov

Received 20 August 2009; revised 4 November 2009; accepted 5 November 2009 emerged from the autism literature. High platelet serotonin is one of the most common biological findings in the autism literature (Cook and Leventhal, 1996), serotonin transporter polymorphisms appear in some autistic individuals (Anderson et al, 2002), and low serotonin during early development produces cortical abnormalities (Boylan et al, 2007; Janusonis et al, 2006; Whitaker-Azmitia, 2005). In knock-in mice with a trypotophan hydroxylase 2 mutation that reduces brain serotonin levels, Gsk $3 \beta$ genetic reduction and inhibition by thiadiazolidinone reversed behavioral abnormalities in anxiety-like and social interaction paradigms (Beaulieu et al, 2008). In clinical studies, selective serotonin reuptake inhibitors (SSRIs), including fluoxetine and citalopram, have produced some therapeutic improvements when targeted to various symptoms (Hollander et al, 2000; Hollander et al, 2005; Kolevzon et al, 2006; Parikh et al, 2008; Soorya et al, 2008). However, a more recent multicenter citalopram trial failed to detect significant behavioral improvements, and reported some adverse effects in children (King et al, 2009; Volkmar, 2009). On the basis of the large literature implicating oxytocin in social affiliation (Ferguson et al, 2001; Winslow et al, 2000; Winslow and Insel, 2002), oxytocin treatments have been 
administered to autistic individuals with some success (Bartz and Hollander, 2008). A recent discovery of synaptic defects in several mouse models of neurodevelopmental disorders has led to the proposal of pharmacotherapeutic targets that may normalize synaptic connectivity. Potential targets include metabotropic glutamate receptor (mGluR) antagonists, AMPA receptor activation, and modulation of intracellular signaling mechanisms such as mTOR and PAK (Bear et al, 2004; Berry-Kravis et al, 2006; Dolen et al, 2007; Ehninger et al, 2008a; Hayashi et al, 2007; Lauterborn et al, 2000; Meikle et al, 2008; Ogier et al, 2007; Price et al, 2007; Simmons et al, 2009; Zhou et al, 2009).

Animal models offer opportunities to test genetic hypotheses and evaluate suggested treatments. One strategy used with success in mice is the forward genetics approach of identifying inbred strains of mice with phenotypes relevant to the symptoms of a human disease (Bolivar et al, 2007; Brodkin, 2007; McFarlane et al, 2008; Moy et al, 2004, 2007, 2008; Nadler et al, 2004), conducting biological assays to understand the mechanisms responsible for the phenotypes, and evaluating pharmacological challenges to discover treatments that reverse the phenotypes. Using forward genetics, along with others, we identified the BTBR $\mathrm{T}+\mathrm{tf} / \mathrm{J}$ (BTBR) strain, which shows multiple behavioral traits with face validity for the diagnostic symptoms of autism. BTBR shows deficits on juvenile and adult reciprocal social interactions, adult social approach, and social transmission of food preference (Bolivar et al, 2007; McFarlane et al, 2008; Moy et al, 2007; Yang et al, 2007a, b, 2009), unusual patterns of vocalization (Scattoni et al, 2008), and high levels of repetitive self-grooming (McFarlane et al, 2008; Yang et al, 2007a, b, 2009) as compared with many other inbred strains of mice (Moy et al, 2007, 2008). Adult social approach deficits and high self-grooming phenotypes, replicated in three laboratories using at least eight independent cohorts of BTBR mice, offer robust behavioral read-outs to evaluate pharmacological compounds, as a first preclinical step toward developing therapeutic interventions for autism.

Our laboratory is interested in the translational application of well-defined mouse models to identify novel pharmacological interventions with efficacy in both autistic children and adults, and in specific subgroups with subsets of symptoms (Bethea and Sikich, 2007; King et al, 2009). Mouse models of monogenic neurodevelopmental disorders have proven useful as translational tools to evaluate potential treatments (Ehninger et al, 2008b). Genetic rescues have been shown in several mouse models of neurodevelopmental disorders, including Rett syndrome Mecp2 mutant mice (Guy et al, 2007; Jugloff et al, 2008) and Fragile X syndrome Fmr1 mutant mice (Dolen et al, 2007; Hayashi et al, 2007; Paylor et al, 2008; Spencer et al, 2008). The pharmacological agent 2-methyl-6-phenylethynyl-pyridine (MPEP), a potent, blood-brain barrier penetrable noncompetitive mGluR5 antagonist, normalized some components of the Fmrl phenotype, including seizures, prepulse inhibition, and reduced excessive dendritic spine densities (Bear et al, 2008; de Vrij et al, 2008; Dolen and Bear, 2008; Yan et al, 2005). We, therefore, chose to analyze the ability of MPEP to modulate the social deficits and repetitive behaviors in $\mathrm{BTBR}$.
Early, intensive behavioral intervention is currently the most effective treatment for the diagnostic symptoms of autism (Landa, 2008; Rao et al, 2008; Williams White et al, 2007). Although a few pharmacological treatments appear to reduce some associated symptoms, none thus far relieve the core symptoms of autism. One drug, the atypical antipsychotic risperidone, has been approved by the United States Food and Drug Administration (FDA) for the treatment of autism, specifically for the treatment of irritability, a descriptor that includes self-injury, aggression, upset to change, and tantrums associated with autism spectrum disorders. As a second test compound, we analyzed the ability of risperidone to modulate the social deficits and repetitive behaviors in BTBR. These studies represent the first in a systematic approach to test prototype compounds for efficacy in reversing autism-relevant phenotypes in the BTBR model system.

\section{MATERIALS AND METHODS}

\section{Mice}

Inbred strains C57BL/6J (B6) and BTBR $\mathrm{T}+\mathrm{tf} / \mathrm{J}$ (BTBR) were purchased from The Jackson Laboratory (Bar Harbor, $\mathrm{ME}$ ) and bred in a conventional mouse vivarium at the National Institute of Mental Health (NIMH), Bethesda, MD, using harem breeding trios. After 2 weeks with a male, females were separated into individual cages before delivery. Pups were kept with the dam until weaning at postnatal day (PND) 21. After weaning, juveniles were housed by sex and strain in standard plastic cages in groups not exceeding four per cage. Cages were housed in ventilated racks in temperature $\left(20^{\circ} \mathrm{C}\right)$ and humidity ( $\sim 55 \%)$ controlled colony rooms, on a 12 -h circadian cycle, lights on from 0700 to $1900 \mathrm{~h}$. Standard rodent chow and tap water were available ad libitum. In addition to standard bedding, a Nestlet square, shredded brown paper and a cardboard tube were provided in each cage. Previous studies in our laboratory documented no sex differences in sociability or self-grooming in BTBR and B6 (McFarlane et al, 2008; Yang et al, 2009). Therefore, male and female mice were used in all studies in approximately equal proportions. Experiments were conducted in dedicated behavioral testing rooms during the standard light phase, usually between 1000 and $1500 \mathrm{~h}$. All procedures were conducted in strict compliance with the NIH Guidelines for the Care and Use of Laboratory Animals and approved by the National Institute of Mental Health Animal Care and Use Committee.

\section{Drug Administration}

MPEP $(0.5,1.0,10.0$, and $30.0 \mathrm{mg} / \mathrm{kg}$, Sigma Aldrich, St Louis, MO) was dissolved in saline $(0.9 \% \mathrm{NaCl})$. Risperidone $(0.125,0.250$, and $0.500 \mathrm{mg} / \mathrm{kg}$, Sigma Aldrich) was dissolved in saline $(0.9 \% \mathrm{NaCl})$ containing $1 \%$ acetic acid. Adult male and female B6 and BTBR mice weighing 25-40 g received an intraperitoneal (i.p.) injection of saline vehicle, MPEP, or risperidone $30 \mathrm{~min}$ before the start of behavioral test sessions for the self-grooming, social approach, and open field behavioral tasks. Behavioral data and in vivo receptor occupancy studies determined the 
post-treatment interval for both MPEP and risperidone (Anderson et al, 2003; Carvalho et al, 2003; Yan et al, 2005). Testing began at ages 6-8 weeks. Treatment groups consisted of 6-10 mice per drug dose or vehicle, with approximately equal numbers of males and females throughout. Each mouse was used only once, for a single behavioral task, receiving a single drug dose. Drug doses were coded to ensure that the raters were blind to the treatment condition.

\section{Behavioral Assays}

Self-grooming. Mice were scored for spontaneous grooming behaviors as described earlier (McFarlane et al, 2008; Yang et al, 2007b). Each mouse was placed individually into a standard mouse cage, $(46 \mathrm{~cm}$ length $\times 23.5 \mathrm{~cm}$ wide $\times 20 \mathrm{~cm}$ high), illuminated at $\sim 40$ lux. A thin $(1 \mathrm{~cm})$ layer of bedding reduced neophobia, while preventing digging; a potentially competing behavior. After a 5-min habituation period in the test cage, each mouse was scored with a stopwatch for $10 \mathrm{~min}$ for cumulative time spent grooming all body regions. The slightly different fur color markings of B6 (dark brown) and BTBR (dark brown with a light brown ventral patch) prevented fully blind rating in real time for self-grooming. However, the observer sat at a distance of approximately $2 \mathrm{~m}$ from the test cage, and was generally unable to identify the strain while scoring self-grooming (McFarlane et al, 2008; Yang et al, 2007b).

Open field locomotion. General exploratory locomotion in a novel open field environment was assessed as described earlier (Bailey et al, 2007), as an independent control for direct drug effects on physical activity that could confound the interpretation of results from the selfgrooming and social approach tasks. Individual mice were placed in a VersaMax Animal Activity Monitoring System (AccuScan Instruments, Columbus, $\mathrm{OH}$ ) for a 30-min test session. The testing room was illuminated with overhead lighting at $\sim 200$ lux. The chambers consisted of clear Plexiglas sides and floor, approximately $40 \times 40 \times 30.5 \mathrm{~cm}$. Mice were placed in the center of the open field at the initiation of the testing session. Photocells at standard heights for recording activity were aligned eight to a side, dividing the chamber into 64 equal squares. Total distance traversed was automatically collected using the Versamax activity monitor and analyzer software system. Test chambers were cleaned with $70 \%$ ethanol between test subjects. At least $5 \mathrm{~min}$ between cleaning and the start of the next session was allowed for ethanol evaporation and odor dissipation.

Sociability. Social approach was tested in an automated three-chambered apparatus using methods described earlier (Chadman et al, 2008; Crawley, 2007; Yang et al, 2007a, 2009). The apparatus was a rectangular, three-chambered box made from clear polycarbonate. Retractable doorways within the two dividing walls allowed access to the side chambers. Number of entries and time spent in the chambers were automatically recorded from photocells embedded in the doorways. A top mounted CCTV camera (Security Cameras Direct, Luling, TX) was placed over the boxes to record the session, for subsequent scoring of the videos for time spent sniffing the novel mouse and novel object. The apparatus was cleaned with $70 \%$ ethanol and water between subjects with at least 5 min between cleaning and the start of the next test session to allow for ethanol evaporation and clearance of ethanol vapor odors. Mice used as the novel stimulus target were $129 \mathrm{~Sv} / \mathrm{ImJ}$, aged 12-20 weeks old, bred and maintained in the NIMH vivarium from breeding pairs originally obtained from The Jackson Laboratory, and matched to the subject mice by sex. Stimulus mice were habituated to the apparatus and to the wire cup enclosure, several days before the start of experiments, for $30 \mathrm{~min}$ during three habituation sessions per day for 2 days. The location (left or right) of the novel object and novel mouse alternated across subjects. The subject mouse was allowed to acclimate to the apparatus for $20 \mathrm{~min}$ before the sociability test, $10 \mathrm{~min}$ in the central chamber with the doors closed, followed by $10 \mathrm{~min}$ in the entire empty arena with the doors open. The subject was then briefly confined to the center chamber while a novel object (inverted wire cup, Galaxy Cup, Kitchen Plus, http:// www.kitchen-plus.com) was placed in one of the side chambers and a novel mouse was placed inside an identical inverted wire cup in the other side chamber. The side containing the novel mouse was alternated across the test session. Novel mice were enclosed in a wire cup to ensure that all social approach was initiated by the subject, and to avoid complications of fighting and sexual activity, although allowing visual, olfactory, auditory, and partial tactile contact through the widely spaced wire bars. A plastic cup (Solo Cup Company, Highland Park, IL) with a lead weight was placed on the top of the inverted wire cups, to prevent climbing and sitting on top of the inverted wire cups during the sociability phase test. Time spent in each chamber and number of entries into each chamber was calculated by the automated software, based on the movements of the subject mouse in sequentially breaking and unbreaking a series of photocell beams embedded in the openings between chambers (Crawley, 2007). Number of entries served as a within-task control for levels of general exploratory locomotion. Lack of innate side preference was confirmed in previous experiments and during the initial 10 min of habituation to the entire arena. After both stimuli were positioned, the doors were simultaneously re-opened and the subject was allowed access to all three chambers for 10 min. An observer uninformed of the drug treatments scored the videos with a stopwatch for cumulative time in which the subject mouse sniffed the target mouse. At the end of each testing day, test chambers were thoroughly cleansed with Alconox (Alconox, White Plains, NY) detergent diluted with warm water, followed by extensive rinsing with hot water and air drying.

\section{Statistical Analysis}

Self-grooming was analyzed with a two-way analysis of variance (ANOVA) followed by a Newman-Keuls post hoc test, using StatView statistical software (Citewise.com, Acton, MA). Open field locomotion was analyzed with repeated measures ANOVA followed by Bonferroni-Dunn or Tukey's post hoc analysis, using SigmaPlot version 11.0 (Systat, San Jose, CA). Social approach was analyzed with a within groups repeated measures ANOVA, using StatView 
software, to compare time spent in the side chambers in the sociability test. Since times spent in each of the three chambers added to $10 \mathrm{~min}$, and therefore were not independent, the test condition factor compared time spent only in the right $v s$ left chambers. Center chamber times are shown in the graphs for illustrative purposes. Time spent sniffing the novel object $v s$ the novel mouse and entries into the side chambers were similarly analyzed. In cases in which the overall ANOVA was significant, the treatment factor for each strain was further analyzed with a one-way ANOVA followed by a Newman-Keuls or Bonferroni-Dunn post hoc to compare each drug dose group to its vehicle control group.

\section{RESULTS}

\section{Reductions in Repetitive Self-Grooming Behavior in BTBR Mice Treated with MPEP, at Doses that Did Not Decrease Locomotion in an Open Field}

Figure 1 illustrates self-grooming scores for B6 and BTBR mice treated with saline vehicle or MPEP doses. Overall
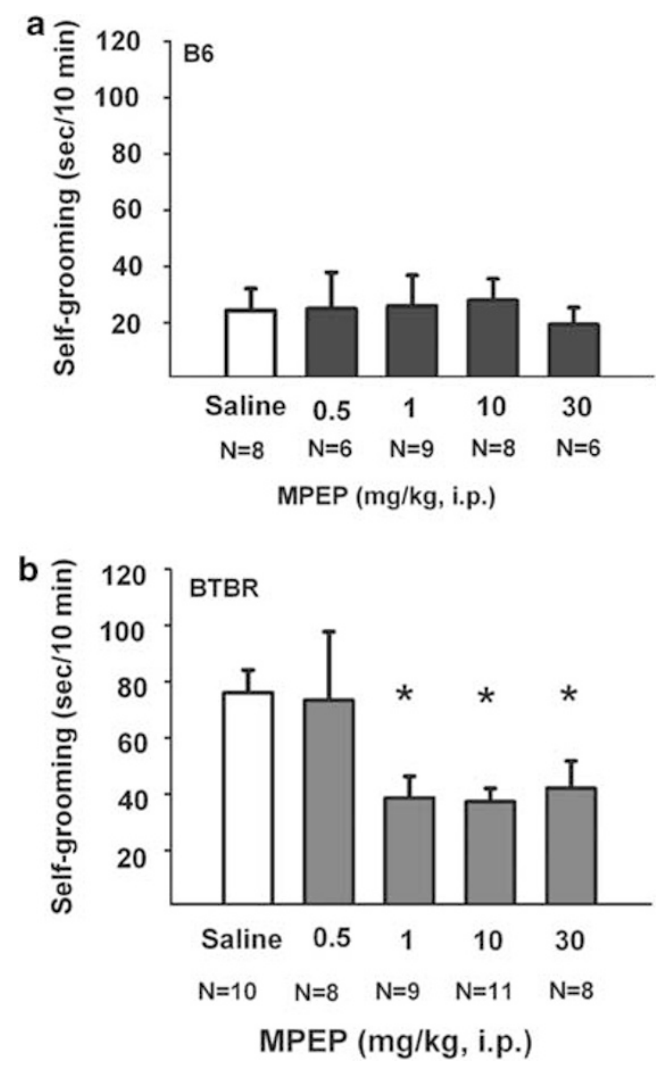

Figure I MPEP reduced self-grooming behavior in BTBR. Cumulative time spent self-grooming was scored over a 10 -min session, for the data shown in Figures $I$ and 5. (a) B6 mice did not show any significant differences in the amount of time spent self-grooming after treatment with saline vehicle or MPEP at doses of $0.5 \mathrm{mg} / \mathrm{kg}, 1.0 \mathrm{mg} / \mathrm{kg}, 10 \mathrm{mg} / \mathrm{kg}$, or $30 \mathrm{mg} /$ kg i. p. (b) BTBR showed significant reductions in their innately high levels of repetitive self-grooming after treatment with MPEP at doses of $1.0 \mathrm{mg} / \mathrm{kg}$, $10 \mathrm{mg} / \mathrm{kg}$, and $30 \mathrm{mg} / \mathrm{kg}$, $* 0.05$ as compared with saline. $N=6-10$ per dose for each strain. Data are shown as \pm SEM in all figures. Significant differences are as compared with vehicle treatment in all figures. Please see Results section for individual post hoc comparisons and statistics for all figures. two-way ANOVA detected a statistically significant difference for strain $\left(F_{(1,81)}=17.22, p<0.0001\right)$ and dose $\left(F_{(4,73)}=2.74, p<0.05\right)$. MPEP had no significant effects on the cumulative self-grooming score of B6 (panel a; $\left.\mathrm{F}_{(4,36)}=0.10, p>0.05\right)$. MPEP significantly reduced repetitive self-grooming scores in BTBR (panel b; $\mathrm{F}_{(4,41)}=4.23$, $p<0.05)$, at treatment doses of $1.0 \mathrm{mg} / \mathrm{kg}(p<0.05), 10 \mathrm{mg} /$ $\mathrm{kg}(p<0.05)$, and $30 \mathrm{mg} / \mathrm{kg}(p<0.05)$ as compared with saline treatment. As described earlier, no sex differences or sex by strain differences were detected in the self-grooming assay at any drug dose treatment.

Figure 2 illustrates the open field exploratory locomotion for both B6 and BTBR after an acute injection of the two highest doses of the MPEP doses that were tested in the selfgrooming assay. The time course for total distance traversed in the novel open field over a 30-min time period was highly significant, as expected, representing habituation to the novel open field by both B6 (panel a; $\mathrm{F}_{(5,20)}=66.92$, $p<0.0001$ ) and BTBR (panel b; $\mathrm{F}_{(5,21)}=65.99, p<0.0001$ ). A significant interaction was detected between strain and total distance traversed $\left(\mathrm{F}_{(5,42)}=8.64, p<0.001\right)$, reflecting the higher initial open field activity of BTBR, as reported earlier (McFarlane et al, 2008; Moy et al, 2007). Of interest is the lack of significant reductions in locomotor activity after
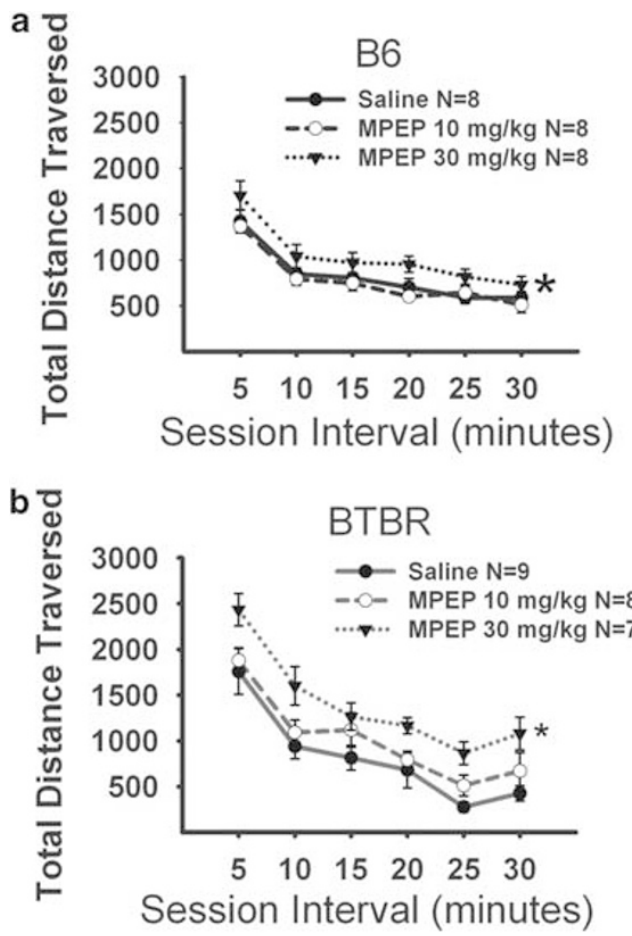

Figure 2 MPEP did not reduce exploratory locomotion. Total distance traversed was assayed in 5-min time bins across a 30-min session in a novel open field arena, for the data shown in Figures 2 and 6. (a) B6 showed no significant reductions in locomotor activity after administration of MPEP at doses of $10 \mathrm{mg} / \mathrm{kg}$. An overall significant increase in activity compared with vehicle was observed for the $30 \mathrm{mg} / \mathrm{kg}$ treatment group $* p<0.05$. Significant increases in total distance during the first and fourth 5 -min interval were observed compared with the $10 \mathrm{mg} / \mathrm{kg}$ dose. (b) BTBR showed no significant reductions in locomotor activity after administration of MPEP at doses of $10 \mathrm{mg} / \mathrm{kg}$ and $30 \mathrm{mg} / \mathrm{kg}$. MPEP increased locomotion at the $30 \mathrm{mg} / \mathrm{kg}$ dose, significant during the first, second, fifth, and sixth 5-min time bins $* p<0.05 . N=7-9$ per dose for each strain. 
MPEP in the strains tested, supporting earlier published literature in rats (Spooren et al, 2000b; Tatarczynska et al, 2001). In fact, slightly higher total distance scores were detected after MPEP administration to B6 (panel a; $\left.\mathrm{F}_{(2,21)}=4.32, p<0.05\right)$ at the $30 \mathrm{mg} / \mathrm{kg}$ dose of MPEP, using a stringent Tukey's post hoc comparison. Similarly, MPEP administration increased total distance scores in BTBR (panel b; $\mathrm{F}_{(2,21)}=6.02, p<0.01$ ). Tukey's post hoc analysis indicated a significant difference between saline and the $30 \mathrm{mg} / \mathrm{kg}$ dose of MPEP $(q=4.87, p<0.05)$, during the first $(q=4.30, p<0.05)$, second $(q=4.20, p<0.05)$, fifth $(q=3.73, p<0.05)$, and sixth $(q=4.14, p<0.05) 5$-min time bin intervals. Supplementary Figures S1 and S2 illustrate additional open field parameters after MPEP administration in the B6 and BTBR. Statistical analyses are provided in the Supplementary Materials.

\section{No Change in Sociability After MPEP Treatment}

Figure 3 illustrates the sociability scores from the automated three-chambered social approach task after a single dose of MPEP or saline in B6. Sociability, defined as spending more time in the chamber with the novel mouse than in the chamber with the novel object, was not significantly different among doses of MPEP and saline for B6 (panel a; $\mathrm{F}_{(3,35)}=38.02, p<0.001$ ). Time spent in the chamber with the novel mouse was significantly greater for all treatment groups (saline, $\mathrm{F}_{(1,8)}=7.29, p<0.05$; MPEP $1.0 \mathrm{mg} / \mathrm{kg}, \quad \mathrm{F}_{(1,9)}=8.42, \quad p<0.05 ; \quad$ MPEP $\quad 10 \mathrm{mg} / \mathrm{kg}$, $\mathrm{F}_{(1,9)}=35.26, \quad p<0.05 ; \quad$ MPEP $30 \mathrm{mg} / \mathrm{kg}, \quad \mathrm{F}_{(1,8)}=11.42$, $p<0.05)$. Similarly, time spent sniffing the novel mouse was greater than time spent sniffing the novel object for all treatment groups (panel b; $\mathrm{F}_{(3,35)}=112.90, p<0.001$ ). Time spent sniffing the novel mouse was significantly greater than time sniffing the novel object after saline treatment $\left(\mathrm{F}_{(1,8)}=18.98, p<0.05\right), \quad$ MPEP $1.0 \mathrm{mg} / \mathrm{kg} \quad\left(\mathrm{F}_{(1,9)}=22.18\right.$, $p<0.05), 10 \mathrm{mg} / \mathrm{kg}\left(\mathrm{F}_{(1,9)}=157.83, p<0.05\right)$, and $30 \mathrm{mg} / \mathrm{kg}$ $\left(\mathrm{F}_{(1,8)}=17.70, p<0.05\right)$. Entries into the side chambers were not affected by MPEP (panel c; $\mathrm{F}_{(3,35)}=0.05, p>0.05$ ), indicating that the drug treatment had no direct effect on exploratory locomotion during the social approach task. No innate side preference was present in B6 during the task, as shown by similar amounts of time in the left and right side chambers during the 10-min habituation session before the start of social testing (panel d; $\mathrm{F}_{(3,35)}=0.01, p>0.05$ ). No sex differences were shown in the $\mathrm{B} 6 \quad\left(\mathrm{~F}_{(1,37)}=0.41\right.$, $p>0.05)$ in the social approach task at any drug dose treatment.

Figure 4 illustrates a replication of previous findings (McFarlane et al, 2008; Yang et al, 2007a, b), showing that

\section{C57BL/6J}

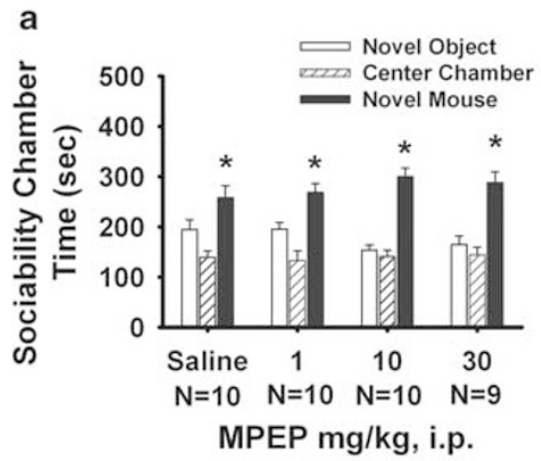

C

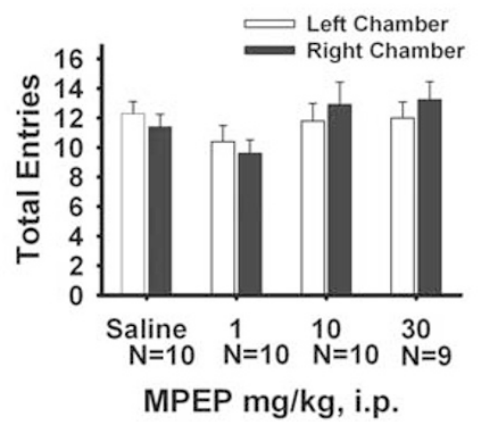

b

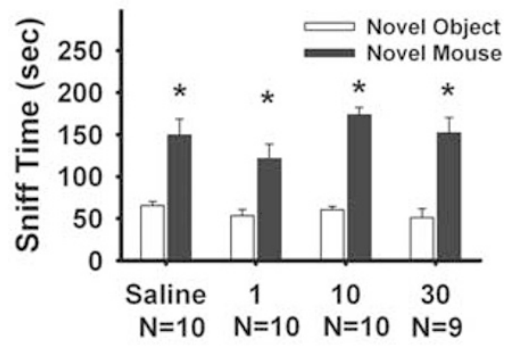

MPEP $\mathrm{mg} / \mathrm{kg}$, i.p.

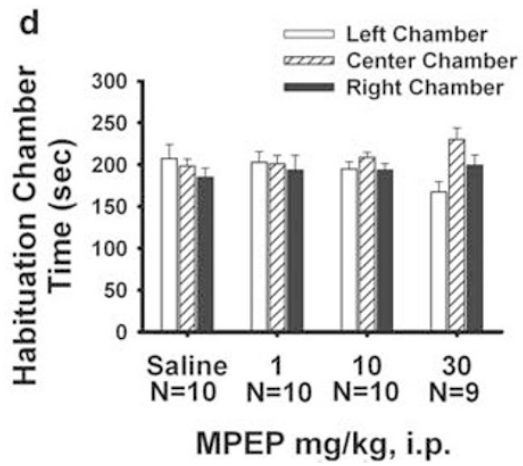

Figure 3 B6 sociability was unaffected by MPEP administration. Social approach was assayed in an automated photocell-equipped three-chambered arena, along with observer scoring of direct sniffing interactions from videotapes of the social approach session, in Figures 3, 4, 7, and 8. (a) B6 showed normal sociability as expected, defined as more time in the side chamber with the novel mouse than in the side chamber with the novel object, after saline and MPEP treatments, $*$ p $<0.05$. (b) B6 showed significantly more time spent sniffing the novel mouse than the novel object, after saline and MPEP treatments, ${ }^{*} p<0.05$ (c) B6 showed no difference in number of entries into the side chambers after MPEP treatment, indicating no drug effect on general exploratory activity during the social approach task. (d) B6 showed no innate chamber side bias during the I0-min habituation phase before the start of the sociability test. $N=8-10$ per dose. 


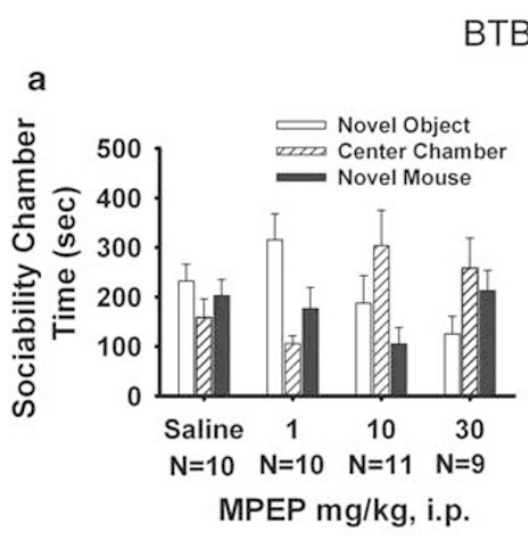

BTBR T+tf/J

C

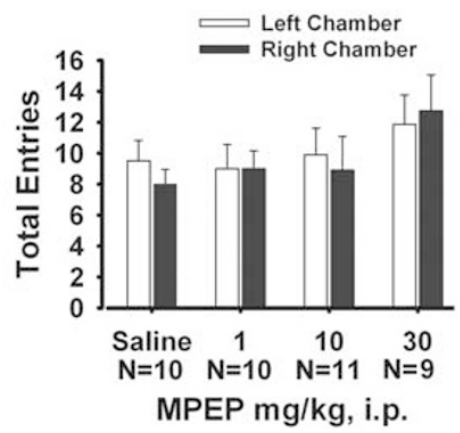

b

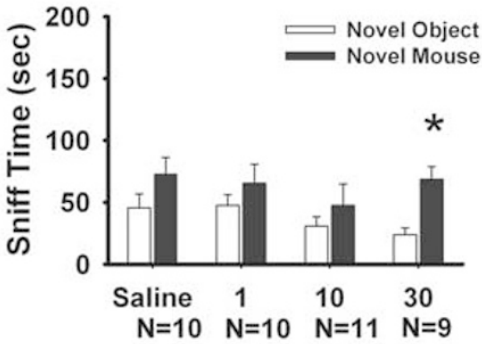

MPEP $\mathrm{mg} / \mathrm{kg}$, i.p.

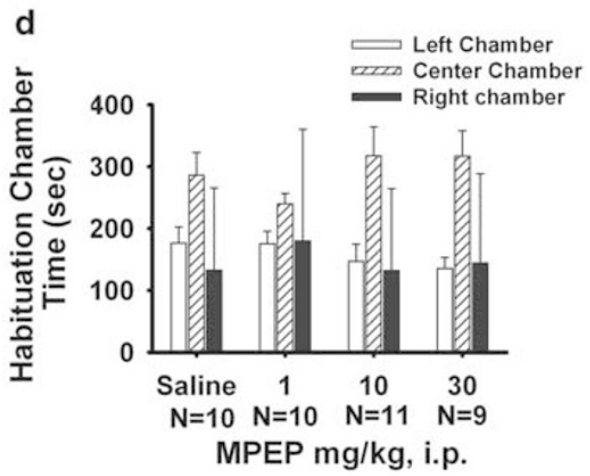

Figure 4 BTBR lack of sociability was unaffected by MPEP administration. (a) BTBR failed to show sociability as expected, spending similar amounts of time in the novel mouse chamber as compared with the novel object chamber after saline treatment. Lack of sociability in BTBR was similarly observed in each MPEP treatment group. (b) BTBR generally did not show significantly more time spent sniffing the novel mouse than the novel object after MPEP treatments. However, increased time spent sniffing was detected in the BTBR group treated with the $30 \mathrm{mg} / \mathrm{kg}$ dose of MPEP (*p<0.05), indicating a trend toward improvement in social interactions. (c) No difference in number of entries into the side chambers was detected after MPEP treatments, indicating no drug effects on general exploratory activity during the sociability task. (d) BTBR showed no innate chamber side bias during the I0-min habituation phase before the start of the sociability test. $N=9-1$ I per dose.

BTBR did not show sociability, defined as no difference between time spent in the side chamber with the novel mouse as compared with time spent in the side chamber with the novel object. MPEP did not improve sociability in BTBR (panel a; $F_{(3,34)}=1.43, p>0.05$ ). Time in the chamber with the novel mouse was similar to time in the chamber with the novel object for each treatment (saline, $\mathrm{F}_{(1,9)}=0.29, \quad p>0.05 ; \quad \mathrm{MPEP} \quad 1.0 \mathrm{mg} / \mathrm{kg} \quad \mathrm{F}_{(1,9)}=2.17$, $p>0.05 ; \quad \mathrm{MPEP} 10 \mathrm{mg} / \mathrm{kg}, \mathrm{F}_{(1,9)}=2.08, \quad p>0.05 ; \mathrm{MPEP}$ $\left.30 \mathrm{mg} / \mathrm{kg}, F_{(1,7)}=3.51, p>0.05\right)$. Time spent sniffing the novel mouse $v s$ the novel object was also not significant in the BTBR for vehicle (panel $b ; F_{(1,6)}=6.30, p>0.05$ ), MPEP $1.0 \mathrm{mg} / \mathrm{kg} \quad\left(\mathrm{F}_{(1,8)}=0.46, \quad p>0.05\right)$, or $\mathrm{MPEP} \quad 10 \mathrm{mg} / \mathrm{kg}$ $\left(\mathrm{F}_{(1,7)}=0.08, p>0.05\right)$. However, increased sniffing in BTBR was detected for the $30 \mathrm{mg} / \mathrm{kg}$ dose of MPEP $\left(F_{(1,7)}=59.58, p<0.05\right)$. Entries into the side chambers were not affected by MPEP, indicating that the drug treatment had no direct effect on exploratory locomotion during the social approach task (panel c; $\mathrm{F}_{(3,34)}=0.39$, $p>0.05)$. No innate side preference was present in BTBR during the task, as shown by similar amounts of time in the left and right side chambers during the 10-min habituation session, before the start of social testing (panel d; $\left.\mathrm{F}_{(3,37)}=0.53, \quad p>0.05\right)$. Replicating previous reports (McFarlane et al, 2008; Yang et al, 2007a,b), no sex differences were detected in BTBR during the social approach task $\left(\mathrm{F}_{(1,36)}=0.26, p>0.05\right)$.

\section{Reductions of Repetitive Self-Grooming Behavior in BTBR Mice Treated with Risperidone, Confounded by Reductions in Open Field}

Figure 5 illustrates self-grooming scores for B6 and BTBR treated with vehicle or risperidone. An overall ANOVA detected a statistical difference in strain $\left(\mathrm{F}_{(1,45)}=7.98\right.$, $p<0.01)$ on repetitive self-grooming, consistent with previous publications and with the findings described above for the MPEP experiment. Risperidone had no significant effects on the cumulative self-grooming score of the $\mathrm{B} 6$ mice (panel a; $\mathrm{F}_{(2,20)}=0.49, p>0.05$ ). Risperidone produced a significant reduction in the high level of repetitive self-grooming in BTBR (panel b; $\mathrm{F}_{(2,21)}=4.47$, $p<0.05)$, at treatment doses $0.125 \mathrm{mg} / \mathrm{kg} \quad(p<0.05)$ and $0.25 \mathrm{mg} / \mathrm{kg}(p<0.05)$.

Figure 6 illustrates open field locomotion after an acute injection of risperidone. The time course for total distance traversed in the novel open field over a 30-min time period was highly significant, as expected, representing habituation to the novel open field for both $\mathrm{B} 6\left(\mathrm{~F}_{(5,40)}=9.04, p<0.0001\right)$ and $\operatorname{BTBR}\left(\mathrm{F}_{(5,33)}=9.55, p<0.0001\right)$. A significant effect of 


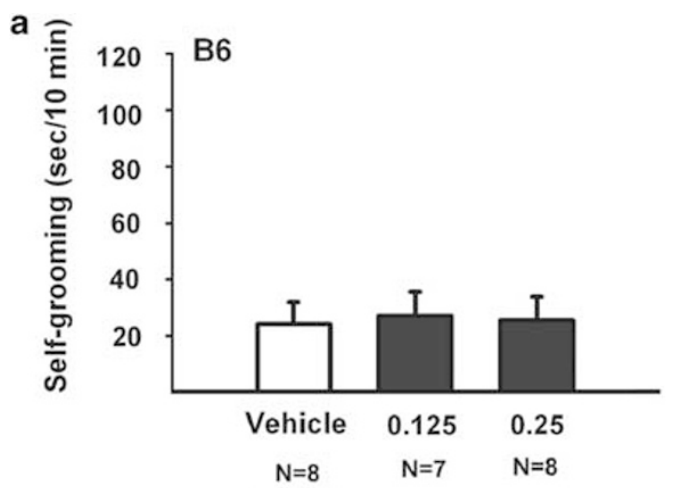

Risperidone ( $\mathrm{mg} / \mathrm{kg}$, i.p.)

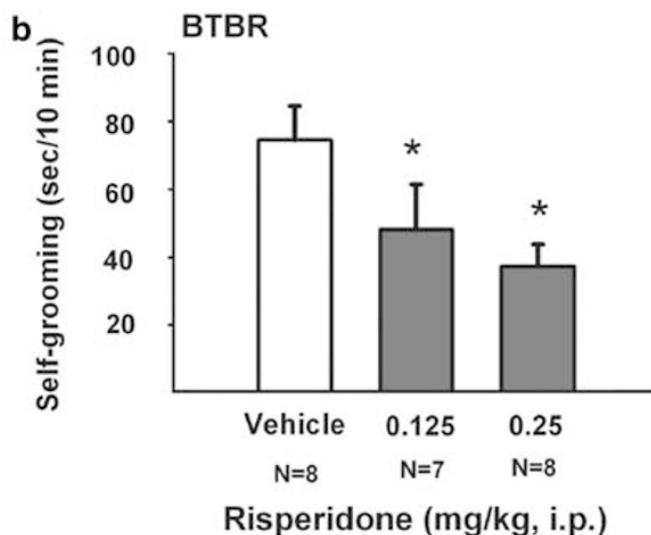

Figure 5 Risperidone reduced self-grooming behavior in BTBR. (a) B6 mice did not show any significant differences in the amount of time spent self-grooming after treatment with risperidone at doses $0.125 \mathrm{mg} / \mathrm{kg}$ and $0.25 \mathrm{mg} / \mathrm{kg}$. (b) BTBR showed significant reductions in their innately high levels of repetitive self-grooming after treatment with risperidone at doses $0.125 \mathrm{mg} / \mathrm{kg}$ and $0.25 \mathrm{mg} / \mathrm{kg}$, as compared with vehicle, ${ }^{*} p<0.05 . \quad N=7-8$ mice per dose.

drug was detected for $\mathrm{B} 6$ (panel a; $\mathrm{F}_{(3,40)}=27.20, p<0.05$ ) and BTBR (panel b; $F_{(3,33)}=11.31, p<0.001$ ). The interaction of drug $\times$ distance traversed was significant for $\mathrm{B} 6$ $\left(\mathrm{F}_{(3,15)}=4.49, p<0.01\right)$ and $\mathrm{BTBR}\left(\mathrm{F}_{(3,15)}=4.29, p<0.01\right)$. Tukey's post hoc comparisons reveal significant reductions in total distance scores after risperidone treatment in B6, at each dose compared with vehicle $(0.125 \mathrm{mg} / \mathrm{kg}, q=8.01$, $p<0.05 ; 0.25 \mathrm{mg} / \mathrm{kg}, q=7.90, p<0.05 ; 0.5 \mathrm{mg} / \mathrm{kg}, q=12.15$, $p<0.05$ ) during the 30-min test session, and at each of the 5 -min time bins. Similarly, significant reductions in open field locomotion were detected in BTBR at each dose of risperidone $(0.125 \mathrm{mg} / \mathrm{kg}, q=3.84, p<0.05 ; 0.25 \mathrm{mg} / \mathrm{kg}$, $q=4.69, p<0.05 ; 0.5 \mathrm{mg} / \mathrm{kg}, q=8.19, p<0.05)$. Additional Tukey's post hoc comparisons in BTBR revealed that the $0.5 \mathrm{mg} / \mathrm{kg}$ dose differed from vehicle at the first $(q=10.70)$, second $(q=7.40)$, third $(q=5.602)$, fourth $(q=5.327)$, and sixth $(q=3.739) 5$-min intervals. In the BTBR, the two lower doses of risperidone reduced locomotion during the first $(0.125 \mathrm{mg} / \mathrm{kg}, q=4.18 ; 0.25 \mathrm{mg} / \mathrm{kg}, q=9.16)$ and second 5 -min intervals $(0.125 \mathrm{mg} / \mathrm{kg}, q=4.35 ; 0.25 \mathrm{mg} / \mathrm{kg}, q=4.88)$. Supplementary Figures S3 and S4 illustrate additional open field parameters after risperidone administration in the $\mathrm{B} 6$
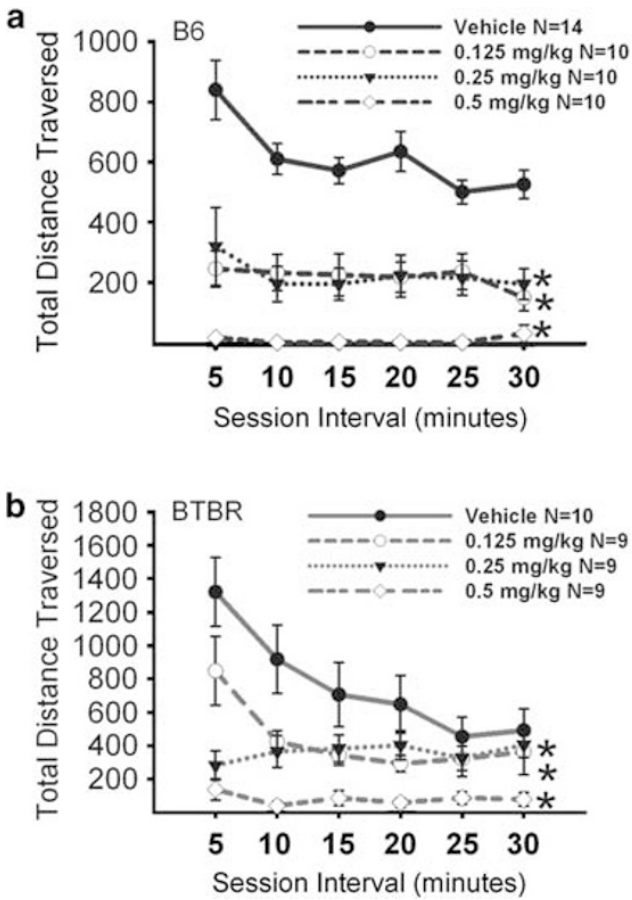

Figure 6 Risperidone reduced exploratory locomotion in an open field. (a) B6 showed significant reductions in locomotor activity after administration of risperidone at doses of $0.125 \mathrm{mg} / \mathrm{kg}, 0.25 \mathrm{mg} / \mathrm{kg}$, and $0.5 \mathrm{mg} / \mathrm{kg}$. (b) BTBR showed significant reductions in locomotor activity after administration of risperidone at doses of $0.125 \mathrm{mg} / \mathrm{kg}, 0.25 \mathrm{mg} / \mathrm{kg}$, and $0.5 \mathrm{mg} / \mathrm{kg}$, during the first and second 5-min time bins $* p<0.05$. Risperidone treatment at a dose of $0.5 \mathrm{mg} / \mathrm{kg}$ reduced locomotion across 5 of the 6 assessed 5 -min time bins * $p<0.05 . N=9-14$ per dose for each strain.

and BTBR. Statistical analyses are provided in the Supplementary Materials.

\section{No Improvement in Sociability After Risperidone Treatment}

Figure 7 illustrates the automated social approach scores after risperidone or vehicle in B6 mice. Normal sociability, as defined previously was displayed by B6 mice after vehicle treatment for time spent in the chamber with the novel mouse (panel a; $\mathrm{F}_{(1,9)}=16.50, p<0.01$ ). Absence of sociability was observed in B6 mice after treatment with risperidone $\left(0.125 \mathrm{mg} / \mathrm{kg}, \mathrm{F}_{(1,9)}=2.37, p>0.05 ; 0.25 \mathrm{mg} / \mathrm{kg}\right.$, $\left.\mathrm{F}_{(1,9)}=1.08, p>0.05 ; 0.5 \mathrm{mg} / \mathrm{kg}, \mathrm{F}_{(1,10)}=1.00, p>0.05\right)$. Moreover, risperidone had a significant effect on the time spent in the chamber with either the novel mouse or novel object $\left(\mathrm{F}_{(3,78)}=39.27, p<0.01\right)$. Between groups ANOVA followed by Bonferroni-Dunn post hoc analysis indicates the $\mathrm{B} 6$ group treated with risperidone $0.5 \mathrm{mg} / \mathrm{kg}$ spent less time in the two-side chambers as compared with the vehicle group $(p<0.001)$. Time spent sniffing the novel mouse was significantly greater than time spent sniffing the novel object for vehicle treatment (panel b; $\mathrm{F}_{(1,9)}=$ $50.36, p<0.001)$ and $0.25 \mathrm{mg} / \mathrm{kg}$ risperidone $\left(\mathrm{F}_{(1,9)}=4.99\right.$, $p<0.05)$ but not for risperidone at $0.125 \mathrm{mg} / \mathrm{kg}\left(\mathrm{F}_{(1,9)}=\right.$ $4.10, p>0.05)$ and $0.5 \mathrm{mg} / \mathrm{kg} \quad\left(\mathrm{F}_{(1,10)}=1.00, p>0.05\right)$. Entries into the side chambers were reduced by risperidone treatment (panel c; $F_{(3,75)}=64.33, p<0.05$ ). Between groups ANOVA revealed significant reductions in entries in B6 $\left(\mathrm{F}_{(3,78)}=70.36, p<0.001\right)$. Bonferroni-Dunn post hoc 
C57BL/6J

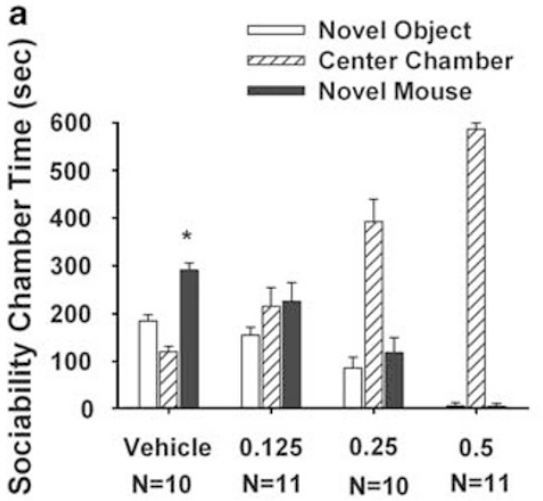

Risperidone $\mathrm{mg} / \mathrm{kg}$, i.p.

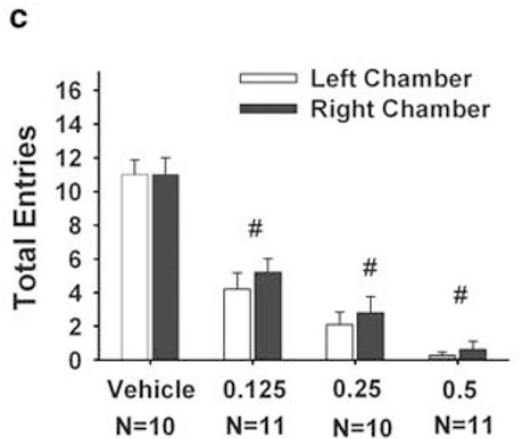

Risperidone $\mathrm{mg} / \mathrm{kg}$, i.p.
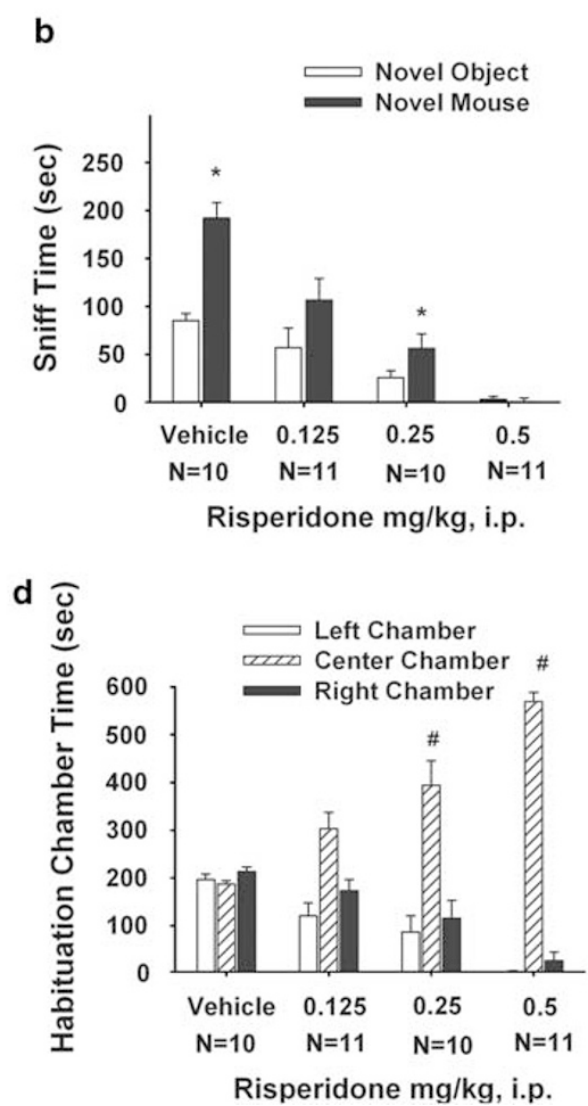

Figure 7 B6 sociability was reduced by risperidone administration. (a) B6 showed significant sociability, as expected, after vehicle treatment, $* p<0.05$. Risperidone reduced normal sociability in B6, resulting in approximately equal low amounts of time spent in the two side chambers, concomitant with more time spent in the center chamber. (b) B6 showed significantly more time spent sniffing the novel mouse than the novel object after vehicle and $0.25 \mathrm{mg} / \mathrm{kg}$ risperidone treatments, $* 0<0.05$, but did not after $0.125 \mathrm{mg} / \mathrm{kg}$ and $0.5 \mathrm{mg} / \mathrm{kg}$ risperidone treatments. (c) B6 showed a reduction in the number of entries into the side chambers, indicating a sedating effect of risperidone during the sociability task ${ }^{\#} p<0.05$. (d) B6 showed no innate chamber side bias during the I0-min habituation phase before the start of the sociability test. $N=8-10$ per dose ${ }^{\#} p<0.05$.

analysis indicated significant differences in number of entries between vehicle and each risperidone dose $0.125 \mathrm{mg} / \mathrm{kg}$ $(p<0.001), \quad 0.25 \mathrm{mg} / \mathrm{kg} \quad(p<0.001)$, and $0.5 \mathrm{mg} / \mathrm{kg} \quad(p<$ $0.001)$, indicating a sedating effect of all three doses of risperidone in $\mathrm{B} 6$. No innate side preference was present in B6 during the 10-min habituation session before the start of social testing after vehicle or risperidone (panel d; $\left.\mathrm{F}_{(1,40)}=3.46, p>0.05\right)$. Bonferroni-Dunn post hoc analysis indicated significantly less time in the left and right side chambers in the risperidone groups at doses $0.25 \mathrm{mg} / \mathrm{kg}$ $(p<0.001)$ and $0.5 \mathrm{mg} / \mathrm{kg}(p<0.001)$. No sex differences in B6 $\left(\mathrm{F}_{(1,39)}=1.101, p>0.05\right)$ were detected in the social approach task at any drug dose treatment.

Figure 8 illustrates automated social approach in the BTBR after risperidone. An overall repeated measures ANOVA indicated that BTBR did not show sociability (panel a; $\mathrm{F}_{(1,41)}=0.73, p>0.05$ ), after vehicle treatment $\left(\mathrm{F}_{(1,9)}=0.43, p>0.05\right)$, risperidone $0.125 \mathrm{mg} / \mathrm{kg}\left(\mathrm{F}_{(1,10)}=\right.$ $0.06, p>0.05)$, risperidone $0.25 \mathrm{mg} / \mathrm{kg} \quad\left(\mathrm{F}_{(1,9)}=0.53, p>\right.$ $0.05)$, and risperidone $0.5 \mathrm{mg} / \mathrm{kg}\left(\mathrm{F}_{(1,10)}=2.66, p>0.05\right)$. A between groups ANOVA indicated a significant effect of risperidone $\left(\mathrm{F}_{(3,80)}=5.08, p<0.01\right)$ on the repeated measure factor of sociability, defined as the time spent in the either the side chamber containing the novel mouse or the side chamber containing the novel object, in BTBR during the sociability phase of testing. Bonferroni-Dunn post hoc analysis detected risperidone at dose $0.5 \mathrm{mg} / \mathrm{kg}$ significantly differing from vehicle $(p<0.005)$. Time spent sniffing the novel mouse $v s$ the novel object was not significant for vehicle or any doses of risperidone tested (panel b; vehicle, $\mathrm{F}_{(1,9)}=1.87, \quad p>0.05 ; 0.125 \mathrm{mg} / \mathrm{kg}$; $\mathrm{F}_{(1,10)}=0.01, p>0.05 ; 0.25 \mathrm{mg} / \mathrm{kg} ; \mathrm{F}_{(1,9)}=1.08, \quad p>0.05$; $\left.0.5 \mathrm{mg} / \mathrm{kg} ; \mathrm{F}_{(1,10)}=1.24, p>0.05\right)$. Reduction in entries into the side chambers were detected by an overall repeated measures ANOVA for entries in BTBR (panel c; $\left.\mathrm{F}_{(3,80)}=39.32, p<0.001\right)$. Between groups ANOVA followed by a Bonferroni-Dunn post hoc analysis detected reduced entries into the left and right side chambers after risperidone at $0.25 \mathrm{mg} / \mathrm{kg}(p<0.01)$ and $0.5 \mathrm{mg} / \mathrm{kg}$ $(p<0.01)$, indicating sedative effects of the drug treatments. No innate side preference was present in BTBR during habituation before the start of social testing after vehicle or risperidone (panel $\mathrm{d} ; \mathrm{F}_{(1,41)}=1.78, p>0.05$ ). BonferroniDunn indicated a significant effect of risperidone during the habituation period by reduced time in the left- and rightside chambers in BTBR after the risperidone dose $0.5 \mathrm{mg} / \mathrm{kg}$ 
BTBR T+tf/J
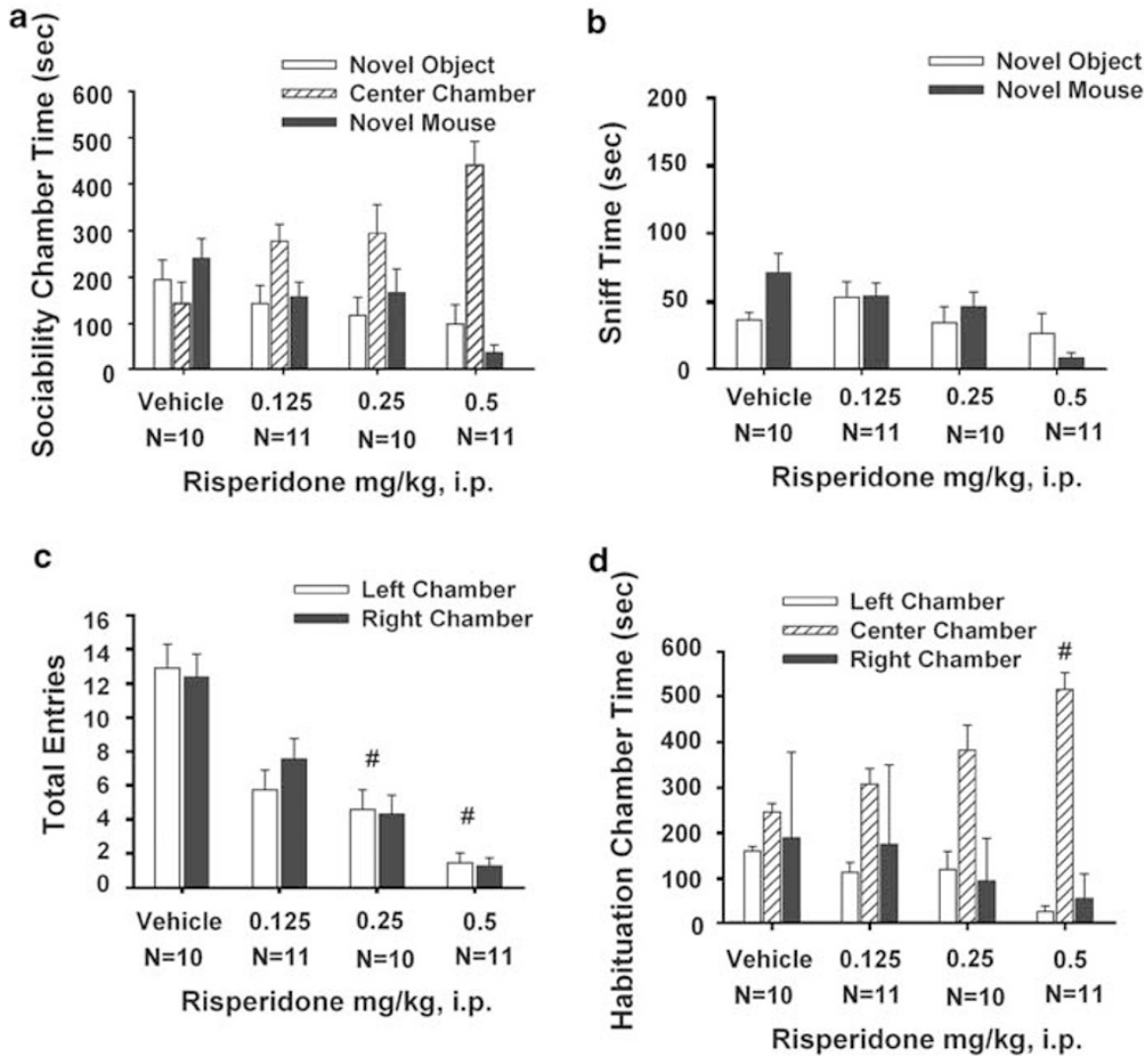

Figure 8 BTBR lack of sociability was unaffected by risperidone administration. (a) BTBR did not show sociability after vehicle or risperidone treatment. (b) BTBR did not show significantly more time spent sniffing the novel mouse than the novel object, after vehicle and risperidone administration. (c) BTBR showed a reduction in the number of entries into the side chambers, indicating a sedating effect of risperidone during the sociability task at doses $0.25 \mathrm{mg} / \mathrm{kg}$ and $0.5 \mathrm{mg} / \mathrm{kg}$, ${ }^{\#} p<0.05$. (d) BTBR showed the normal lack of innate chamber side bias during the I0-min habituation phase before the start of the sociability test, ${ }^{\#} p<0.05 . N=10-1 \mid$ per dose.

$\left({ }^{\#} p<0.001\right)$. No sex differences were detected in BTBR $\left(\mathrm{F}_{(1,39)}=0.04, p>0.05\right)$.

\section{DISCUSSION}

Robust phenotypes in mouse models of autism offer powerful translational tools for discovering effective treatment interventions. Mutant mouse models of monogenic neurodevelopmental disorders, including Fragile X syndrome, Rett syndrome, and tuberous sclerosis, have provided valuable leads in showing symptom reversal by mGluR5 antagonists, rapamycin, and gene rescue (Dolen et al, 2007; Ehninger et al, 2008a; Guy et al, 2007; Kwon et al, 2006; Meikle et al, 2008; Paylor et al, 2008; Spencer et al, 2008; Zhou et al, 2009). MPEP is a prototypical antagonist of the metabotropic glutamate receptor 5 (mGluR5), with an in vitro inhibitory potency $\mathrm{IC}_{50}$ value of $36 \mathrm{nM}$ and an in vivo half life of $45 \mathrm{~min}$ (Anderson et al, 2003; Gasparini et al, 1999; Yan et al, 2005). MPEP effectively reversed several phenotypes in the Fmr1 mutant mouse model of Fragile X syndrome, including hyperactivity, seizures, prepulse inhibition deficits, and remarkable rescues in synaptic plasticity and spine morphology (Bear et al, 2008; de Vrij et al, 2008; Dolen and Bear, 2008; Dolen et al, 2007; Yan et al, 2005). Further, behavioral actions of MPEP included anxiolytic-like effects in standard mice and rats on the elevated plus-maze, stress-induced hyperthermia, marble burying assay, conflict drinking test, and fourplate anxiety assessment (Nordquist et al, 2007; Pilc et al, 2002; Spooren et al, 2000b; Tatarczynska et al, 2001) and analgesic actions in the formalin test, inflammatory pain models, paw pressure, Freund's adjuvant-induced thermal hypersensitivity, and partial sciatic nerve ligation (Montana et al, 2009; Walker et al, 2001a; Walker et al, 2001b). Ligands of the mGluR5 and mGluR2/3 antagonist class may have therapeutic potential for a variety of psychiatric and neurologic disorders and are in clinical trials for Fragile $\mathrm{X}$ treatment (Berry-Kravis et al, 2009; Patil et al, 2007; RorickKehn et al, 2007).

Our results show that MPEP effectively reduced a prominent repetitive behavior in the BTBR mouse model of autism. Doses of 1,10 , and $30 \mathrm{mg} / \mathrm{kg}$ i.p. reduced repetitive self-grooming by approximately $50 \%$. Levels of self-grooming in BTBR treated with MPEP were not significantly different than baseline self-grooming in the B6 control strain. Open field exploratory locomotion was in the normal to high range for these doses of MPEP, indicating the absence of gross motor deficits after MPEP administration in this study, consistent with previous 
published literature using similar dose ranges on motor assessments including the open field and rotarod tasks (Spooren et al, 2000a; Tatarczynska et al, 2001). The efficacy of MPEP in reducing repetitive behavior is a novel finding, adding to the potential therapeutic indications for MPEP, and directly relevant to the third diagnostic symptom of autism.

Repetitive behaviors in autism encompass a variable range of motor stereotypies, self-injurious behavior, compulsions, persistent occupation with parts of objects, preoccupations/restricted patterns of interest, and inflexible adherence to nonfunctional routines/rituals (Bodfish et al, 2000; Lewis et al, 2007; Moy et al, 2008; Richler et al, 2007). Previous indications that MPEP may have anxiolytic-like and analgesic actions (Brodkin et al, 2002; Montana et al, 2009; Spooren et al, 2000b; Tatarczynska et al, 2001; Walker et al, 2001a,b) hold additional promise for mGluR5 antagonist strategies, because associated symptoms of autism include anxiety and elevated pain tolerance in autistic individuals engaged in self-injurious behaviors (Dawson et al, 1998; Towbin et al, 2005; White et al, 2009).

Absence of sociability in BTBR was not reversed by treatment with MPEP. Failure to rescue sociability was not because of a reduction in overall activity, as number of chamber entries during the social task and locomotor activity in an open field were within normal ranges. One report suggested that social exploration was significantly improved with MPEP administration (Spooren et al, 2000b) in rats, using a resident intruder task that measures malemale aggression. Another report showed MPEP rescue of courtship behavior in a Drosophila model of Fragile X (McBride et al, 2005). It is interesting to note that our highest dose MPEP, $30 \mathrm{mg} / \mathrm{kg}$, significantly increased time spent sniffing the novel mouse $v s$ the novel object in BTBR. This preliminary finding suggests that MPEP may have a positive effect on social approach, and highlights the need to test higher doses, multiple injections, or more potent, selective mGluR5 antagonist analogs. MPEP has nonselective effects on NMDA receptors and monoamine oxidase-A (Cosford et al, 2003; Lea and Faden, 2006; Montana et al, 2009; Movsesyan et al, 2001; O'Leary et al, 2000), which may contribute to its actions in mediating neuroprotection in cortical neurons and rats (Movsesyan et al, 2001; O'Leary et al, 2000) and inflammatory pain (Montana et al, 2009). Therefore, the significant increase in sniff time in the BTBR at the $30 \mathrm{mg} / \mathrm{kg}$ dose could be the result of NMDA modulated non-selective actions of MPEP. Our future directions include assessing the more recently developed 3-((2-methyl-1,3-thiazol-4-yl) ethynyl) pyridine (MTEP), which has minimal NMDA inhibition, and is active at lower doses in anxiety-related and pain sensitivity behavioral tasks including the Geller-Seifter conflict test, formalin test, conditioned lick suppression and the Vogel conflict drinking test (Anderson et al, 2003; Busse et al, 2004; Lea and Faden, 2006; Varty et al, 2005), and newer mGluR antagonists in the experimental design described herein.

In contrast to MPEP, risperidone reduced repetitive behavior in BTBR only at doses that were sedating. Risperidone is an atypical antipsychotic, approved specifically to treat irritability associated with autistic disorder in children and adolescents ages 5-16 years, including symptoms of aggression toward others, deliberate selfinjuriousness, temper tantrums, and quickly changing moods (McCracken et al, 2002; McDougle et al, 1997; McDougle et al, 2005). Our experiments assessed the efficacy of acute administration of risperidone at doses shown to block marble burying, hyperlocomotion, prepulse inhibition deficits, and aggressive behaviors in rats and mice (Bruins Slot et al, 2008; Duncan et al, 2006; RodriguezArias et al, 1998). Risperidone at i.p. doses of 0.125 and $0.25 \mathrm{mg} / \mathrm{kg}$ significantly reduced repetitive self-grooming in BTBR, to approximately $40-50 \%$ of vehicle control levels, and only slightly higher than B6 control levels. However, at these doses, risperidone reduced activity in the open field test for exploratory locomotion, and produced major reductions in number of entries into the side chambers of the social approach apparatus, because of mice remaining inactive in the center chamber. Significant reductions in general locomotor activity after risperidone in BTBR mice are consistent with previous reports in B6 and BALB/C mouse strains (Cope et al, 2009; Wagner et al, 2004). Thus, an interpretation of improvement by risperidone in reducing repetitive behaviors in BTBR is confounded by sedation in the present paradigm. In contrast, the clinical literature suggests efficacious and safe use of risperidone for irritability, aggression, hyperactivity, and stereotypy in autism spectrum disorders (McCracken et al, 2002; Wagner et al, 2004). Experimental design for preclinical studies of risperidone in mouse models of autism may require a wider dose range, a different route of administration, and/or a chronic dose regimen. Further, the autism literature describes considerable variability in the clinical benefits of risperidone treatment in improving social or communication skills. Improvements in eye contact and other measures related to social behavior have been reported (Barnard et al, 2002; Chavez et al, 2006; McDougle et al, 1997, 2000; Posey et al, 2008). Minimal or no improvements were reported in social relatedness using the Ritvo Freeman Real Life Rating Scale (Chavez et al, 2006; McDougle et al, 2005). In this study, risperidone failed to improve sociability in the BTBR mouse model. As BTBR mice generally show very low levels of aggression (unpublished observations), low anxiety-like behaviors (McFarlane et al, 2008; Yang et al, 2009), and do not develop any apparent health problems related to their high self-grooming, they do not present a specific model of obsessive compulsive disorder (Welch et al, 2007), self-injurious behavior (Jinnah et al, 1999; Wu and Melton, 1993), or other components of irritability relevant to autism.

At present there is no gold standard, and in fact no active compound, that improves sociability in autism, presenting a major challenge to designing predictive validity into translational testing of compounds in mouse models of autism. A goal of this study was to develop a useful experimental design for testing compounds on sociability in mice. We are generating a prototypical screen, toward discovering active compounds in the social approach task, that reverse phenotypes from lack of sociability to sociability in mouse models of autism.

The experimental design presented herein uses two simple behavioral tasks relevant to the first and third diagnostic symptoms of autism, along with a rapid assessment of adverse locomotor side effects. We are 
beginning to apply this strategy to assess the therapeutic potential of suggested treatments for autism spectrum disorders. Positive findings with the mGluR5 antagonist MPEP indicate the possibility that this class of compounds may have potential for treating preservative, repetitive behaviors. The strong autism-relevant behavioral phenotypes in the BTBR inbred strain, which is genetically homogenous, commercially available, and easy to breed and maintain, offer a first model system, as a prelude to the future use of hypothesis-driven candidate gene mutation mouse models of autism for testing evidence-based pharmacological interventions.

\section{ACKNOWLEDGEMENTS}

The present research was supported by the National Institute of Mental Health Intramural Research Program. We thank Dr Mu Yang and Ms Sarah M Turner for assistance in paper preparation.

\section{DISCLOSURE}

The authors declare no conflict of interest.

\section{REFERENCES}

Abrahams BS, Geschwind DH (2008). Advances in autism genetics: on the threshold of a new neurobiology. Nat Rev Genet 9: 341-355.

Anderson GM, Gutknecht L, Cohen DJ, Brailly-Tabard S, Cohen JH, Ferrari P et al (2002). Serotonin transporter promoter variants in autism: functional effects and relationship to platelet hyperserotonemia. Mol Psychiatry 7: 831-836.

Anderson JJ, Bradbury MJ, Giracello DR, Chapman DF, Holtz G, Roppe J et al (2003). In vivo receptor occupancy of mGlu5 receptor antagonists using the novel radioligand [3H]3-methoxy-5-(pyridin-2-ylethynyl)pyridine). Eur J Pharmacol 473: 35-40.

Bailey KR, Pavlova MN, Rohde AD, Hohmann JG, Crawley JN (2007). Galanin receptor subtype 2 (GalR2) null mutant mice display an anxiogenic-like phenotype specific to the elevated plus-maze. Pharmacol Biochem Behav 86: 8-20.

Barnard L, Young AH, Pearson J, Geddes J, O’Brien G (2002). A systematic review of the use of atypical antipsychotics in autism. J Psychopharmacol 16: 93-101.

Bartz JA, Hollander E (2008). Oxytocin and experimental therapeutics in autism spectrum disorders. Prog Brain Res 170: 451-462.

Bear MF, Dolen G, Osterweil E, Nagarajan N (2008). Fragile X: translation in action. Neuropsychopharmacology 33: 84-87.

Bear MF, Huber KM, Warren ST (2004). The mGluR theory of fragile X mental retardation. Trends Neurosci 27: 370-377.

Beaulieu JM, Zhang X, Rodriguiz RM, Sotnikova TD, Cools MJ, Wetsel WC et al (2008). Role of GSK3 beta in behavioral abnormalities induced by serotonin deficiency. Proc Natl Acad Sci USA 105: 1333-1338.

Berry-Kravis E, Hessl D, Coffey S, Hervey C, Schneider A, Yuhas J et al (2009). A pilot open label, single dose trial of fenobam in adults with fragile X syndrome. J Med Genet 46: 266-271.

Berry-Kravis E, Krause SE, Block SS, Guter S, Wuu J, Leurgans S et al (2006). Effect of CX516, an AMPA-modulating compound, on cognition and behavior in fragile $\mathrm{X}$ syndrome: a controlled trial. J Child Adolesc Psychopharmacol 16: 525-540.
Bethea TC, Sikich L (2007). Early pharmacological treatment of autism: a rationale for developmental treatment. Biol Psychiatry 61: 521-537.

Bodfish JW, Symons FJ, Parker DE, Lewis MH (2000). Varieties of repetitive behavior in autism: comparisons to mental retardation. J Autism Dev Disord 30: 237-243.

Bolivar VJ, Walters SR, Phoenix JL (2007). Assessing autism-like behavior in mice: variations in social interactions among inbred strains. Behav Brain Res 176: 21-26.

Bourgeron T (2009). A synaptic trek to autism. Curr Opin Neurobiol 19: 231-234.

Boylan CB, Blue ME, Hohmann CF (2007). Modeling early cortical serotonergic deficits in autism. Behav Brain Res 176: 94-108.

Brodkin ES (2007). BALB/c mice: low sociability and other phenotypes that may be relevant to autism. Behav Brain Res 176: 53-65.

Brodkin J, Busse C, Sukoff SJ, Varney MA (2002). Anxiolytic-like activity of the mGluR5 antagonist MPEP a comparison with diazepam and buspirone. Pharmacol Biochem Behav 73: 359-366.

Bruins Slot LA, Bardin L, Auclair AL, Depoortere R, NewmanTancredi A (2008). Effects of antipsychotics and reference monoaminergic ligands on marble burying behavior in mice. Behav Pharmacol 19: 145-152.

Busse CS, Brodkin J, Tattersall D, Anderson JJ, Warren N, Tehrani $\mathrm{L}$ et al (2004). The behavioral profile of the potent and selective mGlu5 receptor antagonist 3-[(2-methyl-1,3-thiazol-4-yl)ethynyl]pyridine (MTEP) in rodent models of anxiety. Neuropsychopharmacology 29: 1971-1979.

Buxbaum JD (2009). Multiple rare variants in the etiology of autism spectrum disorders. Dialogues Clin Neurosci 11: $35-43$.

Carvalho RC, Silva RH, Abilio VC, Barbosa PN, Frussa-Filho R (2003). Antidyskinetic effects of risperidone on animal models of tardive dyskinesia in mice. Brain Res Bull 60: 115-124.

Chadman KK, Gong S, Scattoni ML, Boltuck SE, Gandhy SU, Heintz $\mathrm{N}$ et al (2008). Minimal aberrant behavioral phenotypes of neuroligin-3 R451C knockin mice. Autism Res 1: 147-158.

Chavez B, Chavez-Brown M, Rey JA (2006). Role of risperidone in children with autism spectrum disorder. Ann Pharmacother 40: 909-916.

Cook EH, Leventhal BL (1996). The serotonin system in autism. Curr Opin Pediatr 8: 348-354.

Cope MB, Li X, Jumbo-Lucioni P, DiCostanzo CA, Jamison WG, Kesterson RA et al (2009). Risperidone alters food intake, core body temperature, and locomotor activity in mice. Physiol Behav 96: 457-463.

Cosford ND, Roppe J, Tehrani L, Schweiger EJ, Seiders TJ, Chaudary A et al (2003). [3H]-methoxymethyl-MTEP and [3H]methoxy-PEPy: potent and selective radioligands for the metabotropic glutamate subtype 5 (mGlu5) receptor. Bioorg Med Chem Lett 13: 351-354.

Crawley JN (2007). Mouse behavioral assays relevant to the symptoms of autism. Brain Pathol 17: 448-459.

Dawson JE, Matson JL, Cherry KE (1998). An analysis of maladaptive behaviors in persons with autism, PDD-NOS, and mental retardation. Res Dev Disabil 19: 439-448.

de Vrij FM, Levenga J, van der Linde HC, Koekkoek SK, De Zeeuw CI, Nelson DL et al (2008). Rescue of behavioral phenotype and neuronal protrusion morphology in Fmr1 KO mice. Neurobiol Dis 31: 127-132.

DiCicco-Bloom E, Lord C, Zwaigenbaum L, Courchesne E, Dager SR, Schmitz C et al (2006). The developmental neurobiology of autism spectrum disorder. J Neurosci 26: 6897-6906.

Dolen G, Bear MF (2008). Role for metabotropic glutamate receptor 5 (mGluR5) in the pathogenesis of fragile X syndrome. J Physiol 586: 1503-1508. 
Dolen G, Osterweil E, Rao BS, Smith GB, Auerbach BD, Chattarji S et al (2007). Correction of fragile $\mathrm{X}$ syndrome in mice. Neuron 56: $955-962$.

Duncan GE, Moy SS, Lieberman JA, Koller BH (2006). Typical and atypical antipsychotic drug effects on locomotor hyperactivity and deficits in sensorimotor gating in a genetic model of NMDA receptor hypofunction. Pharmacol Biochem Behav 85: 481-491.

Ehninger D, Han S, Shilyansky C, Zhou Y, Li W, Kwiatkowski DJ et al (2008a). Reversal of learning deficits in a Tsc2+/- mouse model of tuberous sclerosis. Nat Med 14: 843-848.

Ehninger D, Li W, Fox K, Stryker MP, Silva AJ (2008b). Reversing neurodevelopmental disorders in adults. Neuron 60: 950-960.

Ferguson JN, Aldag JM, Insel TR, Young LJ (2001). Oxytocin in the medial amygdala is essential for social recognition in the mouse. J Neurosci 21: 8278-8285.

Gasparini F, Lingenhohl K, Stoehr N, Flor PJ, Heinrich M, Vranesic I et al (1999). 2-Methyl-6-(phenylethynyl)-pyridine (MPEP), a potent, selective and systemically active mGlu5 receptor antagonist. Neuropharmacology 38: 1493-1503.

Geschwind DH, Sowinski J, Lord C, Iversen P, Shestack J, Jones P et al (2001). The autism genetic resource exchange: a resource for the study of autism and related neuropsychiatric conditions. Am J Hum Genet 69: 463-466.

Guy J, Gan J, Selfridge J, Cobb S, Bird A (2007). Reversal of neurological defects in a mouse model of Rett syndrome. Science 315: 1143-1147.

Happe F, Ronald A (2008). The 'fractionable autism triad': a review of evidence from behavioural, genetic, cognitive and neural research. Neuropsychol Rev 18: 287-304.

Hayashi ML, Rao BS, Seo JS, Choi HS, Dolan BM, Choi SY et al (2007). Inhibition of p21-activated kinase rescues symptoms of fragile X syndrome in mice. Proc Natl Acad Sci USA 104: 11489-11494.

Hollander E, Novotny S, Allen A, Aronowitz B, Cartwright C, DeCaria C (2000). The relationship between repetitive behaviors and growth hormone response to sumatriptan challenge in adult autistic disorder. Neuropsychopharmacology 22: 163-167.

Hollander E, Phillips A, Chaplin W, Zagursky K, Novotny S, Wasserman S et al (2005). A placebo controlled crossover trial of liquid fluoxetine on repetitive behaviors in childhood and adolescent autism. Neuropsychopharmacology 30: 582-589.

Janusonis S, Anderson GM, Shifrovich I, Rakic P (2006). Ontogeny of brain and blood serotonin levels in 5-HT receptor knockout mice: potential relevance to the neurobiology of autism. J Neurochem 99: 1019-1031.

Jinnah HA, Yitta S, Drew T, Kim BS, Visser JE, Rothstein JD (1999). Calcium channel activation and self-biting in mice. Proc Natl Acad Sci USA 96: 15228-15232.

Jugloff DG, Vandamme K, Logan R, Visanji NP, Brotchie JM, Eubanks JH (2008). Targeted delivery of an Mecp2 transgene to forebrain neurons improves the behavior of female Mecp2deficient mice. Hum Mol Genet 17: 1386-1396.

King BH, Hollander E, Sikich L, McCracken JT, Scahill L, Bregman JD et al (2009). Lack of efficacy of citalopram in children with autism spectrum disorders and high levels of repetitive behavior: citalopram ineffective in children with autism. Arch Gen Psychiatry 66: 583-590.

Kolevzon A, Mathewson KA, Hollander E (2006). Selective serotonin reuptake inhibitors in autism: a review of efficacy and tolerability. J Clin Psychiatry 67: 407-414.

Kwon CH, Luikart BW, Powell CM, Zhou J, Matheny SA, Zhang W et al (2006). Pten regulates neuronal arborization and social interaction in mice. Neuron 50: 377-388.

Landa RJ (2008). Diagnosis of autism spectrum disorders in the first 3 years of life. Nat Clin Pract Neurol 4: 138-147.

Lauterborn JC, Lynch G, Vanderklish P, Arai A, Gall CM (2000). Positive modulation of AMPA receptors increases neurotrophin expression by hippocampal and cortical neurons. J Neurosci 20: $8-21$.

Lea IV PM, Faden AI (2006). Metabotropic glutamate receptor subtype 5 antagonists MPEP and MTEP. CNS Drug Rev 12: 149-166.

Lewis MH, Tanimura Y, Lee LW, Bodfish JW (2007). Animal models of restricted repetitive behavior in autism. Behav Brain Res 176: 66-74.

Lintas C, Persico AM (2009). Autistic phenotypes and genetic testing: state-of-the-art for the clinical geneticist. J Med Genet 46: $1-8$.

Lord C, Cook EH, Leventhal BL, Amaral DG (2000). Autism spectrum disorders. Neuron 28: 355-363.

McBride SM, Choi CH, Wang Y, Liebelt D, Braunstein E, Ferreiro D et al (2005). Pharmacological rescue of synaptic plasticity, courtship behavior, and mushroom body defects in a Drosophila model of fragile X syndrome. Neuron 45: 753-764.

McCracken JT, McGough J, Shah B, Cronin P, Hong D, Aman MG et al (2002). Risperidone in children with autism and serious behavioral problems. $N$ Engl J Med 347: 314-321.

McDougle CJ, Holmes JP, Bronson MR, Anderson GM, Volkmar FR, Price LH et al (1997). Risperidone treatment of children and adolescents with pervasive developmental disorders: a prospective open-label study. J Am Acad Child Adolesc Psychiatry 36: 685-693.

McDougle CJ, Scahill L, Aman MG, McCracken JT, Tierney E, Davies $M$ et al (2005). Risperidone for the core symptom domains of autism: results from the study by the autism network of the research units on pediatric psychopharmacology. Am J Psychiatry 162: 1142-1148.

McDougle CJ, Scahill L, McCracken JT, Aman MG, Tierney E, Arnold LE et al (2000). Research Units on Pediatric Psychopharmacology (RUPP) Autism Network. Background and rationale for an initial controlled study of risperidone. Child Adolesc Psychiatr Clin N Am 9: 201-224.

McFarlane HG, Kusek GK, Yang M, Phoenix JL, Bolivar VJ, Crawley JN (2008). Autism-like behavioral phenotypes in BTBR $\mathrm{T}+\mathrm{tf} / \mathrm{J}$ mice. Genes Brain Behav 7: 152-163.

Meikle L, Pollizzi K, Egnor A, Kramvis I, Lane H, Sahin M et al (2008). Response of a neuronal model of tuberous sclerosis to mammalian target of rapamycin (mTOR) inhibitors: effects on mTORC1 and Akt signaling lead to improved survival and function. J Neurosci 28: 5422-5432.

Montana MC, Cavallone LF, Stubbert KK, Stefanescu AD, Kharasch ED, Gereau RW (2009). The mGlu5 antagonist fenobam is analgesic and has improved in vivo selectivity as compared to the prototypical antagonist MPEP. J Pharmacol Exp Ther 330: 834-843.

Movsesyan VA, O'Leary DM, Fan L, Bao W, Mullins PG, Knoblach SM et al (2001). mGluR5 antagonists 2-methyl-6-(phenylethynyl)-pyridine and (E)-2-methyl-6-(2-phenylethenyl)-pyridine reduce traumatic neuronal injury in vitro and in vivo by antagonizing N-methyl-D-aspartate receptors. J Pharmacol Exp Ther 296: 41-47.

Moy SS, Nadler JJ, Perez A, Barbaro RP, Johns JM, Magnuson TR et al (2004). Sociability and preference for social novelty in five inbred strains: an approach to assess autistic-like behavior in mice. Genes Brain Behav 3: 287-302.

Moy SS, Nadler JJ, Young NB, Nonneman RJ, Segall SK, Andrade GM et al (2008). Social approach and repetitive behavior in eleven inbred mouse strains. Behav Brain Res 191: 118-129.

Moy SS, Nadler JJ, Young NB, Perez A, Holloway LP, Barbaro RP et al (2007). Mouse behavioral tasks relevant to autism: phenotypes of 10 inbred strains. Behav Brain Res 176: 4-20.

Nadler JJ, Moy SS, Dold G, Trang D, Simmons N, Perez A et al (2004). Automated apparatus for quantitation of social approach behaviors in mice. Genes Brain Behav 3: 303-314. 
Nordquist RE, Durkin S, Jaeschke G, Spooren W (2007). Stressinduced hyperthermia: effects of acute and repeated dosing of MPEP. Eur J Pharmacol 568: 199-202.

O'Leary DM, Movsesyan V, Vicini S, Faden AI (2000). Selective mGluR5 antagonists MPEP and SIB-1893 decrease NMDA or glutamate-mediated neuronal toxicity through actions that reflect NMDA receptor antagonism. Br J Pharmacol 131: 1429-1437.

Ogier M, Wang H, Hong E, Wang Q, Greenberg ME, Katz DM (2007). Brain-derived neurotrophic factor expression and respiratory function improve after ampakine treatment in a mouse model of Rett syndrome. J Neurosci 27: 10912-10917.

Parikh MS, Kolevzon A, Hollander E (2008). Psychopharmacology of aggression in children and adolescents with autism: a critical review of efficacy and tolerability. J Child Adolesc Psychopharmacol 18: 157-178.

Patil ST, Zhang L, Martenyi F, Lowe SL, Jackson KA, Andreev BV et al (2007). Activation of $\mathrm{mGlu} 2 / 3$ receptors as a new approach to treat schizophrenia: a randomized phase 2 clinical trial. Nat Med 13: 1102-1107.

Paylor R, Yuva-Paylor LA, Nelson DL, Spencer CM (2008). Reversal of sensorimotor gating abnormalities in Fmr1 knockout mice carrying a human Fmr1 transgene. Behav Neurosci 122: 1371-1377.

Persico AM, Bourgeron T (2006). Searching for ways out of the autism maze: genetic, epigenetic and environmental clues. Trends Neurosci 29: 349-358.

Pilc A, Klodzinska A, Branski P, Nowak G, Palucha A, Szewczyk B et al (2002). Multiple MPEP administrations evoke anxiolyticand antidepressant-like effects in rats. Neuropharmacology 43: 181-187.

Posey DJ, Erickson CA, McDougle CJ (2008). Developing drugs for core social and communication impairment in autism. Child Adolesc Psychiatr Clin N Am 17: 787-801, viii-ix.

Price TJ, Rashid MH, Millecamps M, Sanoja R, Entrena JM, Cervero F (2007). Decreased nociceptive sensitization in mice lacking the fragile $\mathrm{X}$ mental retardation protein: role of mGluR1/ 5 and mTOR. J Neurosci 27: 13958-13967.

Rao PA, Beidel DC, Murray MJ (2008). Social skills interventions for children with Asperger's syndrome or high-functioning autism: a review and recommendations. J Autism Dev Disord 38: 353-361.

Richler J, Bishop SL, Kleinke JR, Lord C (2007). Restricted and repetitive behaviors in young children with autism spectrum disorders. J Autism Dev Disord 37: 73-85.

Rodriguez-Arias M, Minarro J, Aguilar MA, Pinazo J, Simon VM (1998). Effects of risperidone and SCH 23390 on isolationinduced aggression in male mice. Eur Neuropsychopharmacol 8: 95-103.

Rorick-Kehn LM, Johnson BG, Knitowski KM, Salhoff CR, Witkin JM, Perry KW et al (2007). In vivo pharmacological characterization of the structurally novel, potent, selective mGlu2/3 receptor agonist LY404039 in animal models of psychiatric disorders. Psychopharmacology (Berl) 193: 121-136.

Scattoni ML, Gandhy SU, Ricceri L, Crawley JN (2008). Unusual repertoire of vocalizations in the BTBR $\mathrm{T}+\mathrm{tf} / \mathrm{J}$ mouse model of autism. PLOS ONE 3: e3067.

Simmons DA, Rex CS, Palmer L, Pandyarajan V, Fedulov V, Gall $\mathrm{CM}$ et al (2009). Up-regulating BDNF with an ampakine rescues synaptic plasticity and memory in Huntington's disease knockin mice. Proc Natl Acad Sci USA 106: 4906-4911.

Soorya L, Kiarashi J, Hollander E (2008). Psychopharmacologic interventions for repetitive behaviors in autism spectrum disorders. Child Adolesc Psychiatr Clin N Am 17: 753-771, viii.

Spencer CM, Graham DF, Yuva-Paylor LA, Nelson DL, Paylor R (2008). Social behavior in Fmr1 knockout mice carrying a human FMR1 transgene. Behav Neurosci 122: 710-715.
Spooren WP, Gasparini F, Bergmann R, Kuhn R (2000a). Effects of the prototypical $\mathrm{mGlu}(5)$ receptor antagonist 2-methyl-6(phenylethynyl)-pyridine on rotarod, locomotor activity and rotational responses in unilateral 6-OHDA-lesioned rats. Eur J Pharmacol 406: 403-410.

Spooren WP, Vassout A, Neijt HC, Kuhn R, Gasparini F, Roux S et al (2000b). Anxiolytic-like effects of the prototypical metabotropic glutamate receptor 5 antagonist 2-methyl-6(phenylethynyl)pyridine in rodents. J Pharmacol Exp Ther 295: 1267-1275.

Tatarczynska E, Klodzinska A, Chojnacka-Wojcik E, Palucha A, Gasparini F, Kuhn R et al (2001). Potential anxiolytic- and antidepressant-like effects of MPEP, a potent, selective and systemically active mGlu5 receptor antagonist. $\mathrm{Br} J$ Pharmacol 132: $1423-1430$.

Towbin KE, Pradella A, Gorrindo T, Pine DS, Leibenluft E (2005). Autism spectrum traits in children with mood and anxiety disorders. J Child Adolesc Psychopharmacol 15: 452-464.

Varty GB, Grilli M, Forlani A, Fredduzzi S, Grzelak ME, Guthrie $\mathrm{DH}$ et al (2005). The antinociceptive and anxiolytic-like effects of the metabotropic glutamate receptor 5 (mGluR5) antagonists, MPEP and MTEP, and the mGluR1 antagonist, LY456236, in rodents: a comparison of efficacy and side-effect profiles. Psychopharmacology (Berl) 179: 207-217.

Volkmar FR (2009). Citalopram treatment in children with autism spectrum disorders and high levels of repetitive behavior. Arch Gen Psychiatry 66: 581-582.

Wagner GC, Avena N, Kita T, Nakashima T, Fisher $\mathrm{H}$, Halladay AK (2004). Risperidone reduction of amphetamineinduced self-injurious behavior in mice. Neuropharmacology 46: 700-708.

Walker K, Bowes M, Panesar M, Davis A, Gentry C, Kesingland A et al (2001a). Metabotropic glutamate receptor subtype 5 (mGlu5) and nociceptive function. I. Selective blockade of mGlu5 receptors in models of acute, persistent and chronic pain. Neuropharmacology 40: 1-9.

Walker K, Reeve A, Bowes M, Winter J, Wotherspoon G, Davis A et al (2001b). mGlu5 receptors and nociceptive function II. mGlu5 receptors and functionally expressed on peripheral sensory neurones mediate inflammatory hyperalgesia. Neuropharmacology 40: 10-19.

Welch JM, Lu J, Rodriguiz RM, Trotta NC, Peca J, Ding JD et al (2007). Cortico-striatal synaptic defects and OCD-like behaviours in Sapap3-mutant mice. Nature 448: 894-900.

Whitaker-Azmitia PM (2005). Behavioral and cellular consequences of increasing serotonergic activity during brain development: a role in autism? Int J Dev Neurosci 23: 75-83.

White SW, Oswald D, Ollendick T, Scahill L (2009). Anxiety in children and adolescents with autism spectrum disorders. Clin Psychol Rev 29: 216-229.

Williams White S, Keonig K, Scahill L (2007). Social skills development in children with autism spectrum disorders: a review of the intervention research. J Autism Dev Disord 37: $1858-1868$.

Winslow JT, Hearn EF, Ferguson J, Young LJ, Matzuk MM, Insel TR (2000). Infant vocalization, adult aggression, and fear behavior of an oxytocin null mutant mouse. Horm Behav 37: 145-155.

Winslow JT, Insel TR (2002). The social deficits of the oxytocin knockout mouse. Neuropeptides 36: 221-229.

Wu CL, Melton DW (1993). Production of a model for LeschNyhan syndrome in hypoxanthine phosphoribosyltransferasedeficient mice. Nat Genet 3: 235-240.

Yan QJ, Rammal M, Tranfaglia M, Bauchwitz RP (2005). Suppression of two major Fragile $\mathrm{X}$ syndrome mouse model phenotypes by the mGluR 5 antagonist MPEP. Neuropharmacology 49: 1053-1066. 
Yang M, Clarke AM, Crawley JN (2009). Postnatal lesion evidence against a primary role for the corpus callosum in mouse sociability. Eur J Neurosci 29: 1663-1677.

Yang M, Scattoni ML, Zhodzishsky V, Chen T, Caldwell H, Young WS et al (2007a). Social approach behaviors are similar on conventional versus reverse lighting cycles, and in replications across cohorts, in BTBR $\mathrm{T}+\mathrm{tf} / \mathrm{J}, \mathrm{C} 57 \mathrm{BL} / 6 \mathrm{~J}$, and vasopressin receptor 1B mutant mice. Front Behav Neurosci 1: 1.
Yang M, Zhodzishsky V, Crawley JN (2007b). Social deficits in BTBR T+tf/J mice are unchanged by cross-fostering with C57BL/ 6J mothers. Int J Dev Neurosci 25: 515-521.

Zhou J, Blundell J, Ogawa S, Kwon CH, Zhang W, Sinton C et al (2009). Pharmacological inhibition of mTORC1 suppresses anatomical, cellular, and behavioral abnormalities in neural-specific Pten knock-out mice. J Neurosci 29: 1773-1783.

Supplementary Information accompanies the paper on the Neuropsychopharmacology website (http://www.nature.com/npp) 